\title{
Response of potato clones to planting dates in Pokhara, Kaski, Nepal
}

\author{
Saroj Adhikari ${ }^{1 *}$, Arvind Kumar Srivastava ${ }^{2}$, Mohadutta Sharma $^{2}$ and Arjun Kumar Shrestha ${ }^{2}$ \\ ${ }^{1}$ Horticulture Research Station, Malepatan, Pokhara, Nepal \\ ${ }^{2}$ Agriculture and Forestry University, Rampur, Chitwan, Nepal \\ *Correspondence: sarojadhikari977@ gmail.com \\ *ORCUD: https://orcid.org/0000-0002-9288-7264 \\ Received: June 27, 2020; Accepted: October 12, 2020; Published: October 30, 2020
}

(C) Copyright: Adhikari et al. (2020)

(c) (1) Th International License.

\begin{abstract}
A field trial was conducted to optimize the planting date and appropriate clone for ware potato production at Horticulture Research Station, Malepatan, Pokhara from October 2015 to March 2016. The trial was laid out in two factors Factorial Randomized Complete Block Design. There were nine treatments with three replications. The treatments comprised of three dates of planting $\left(30^{\text {th }}\right.$ October, $14^{\text {th }}$ and $29^{\text {th }}$ November) and three potato clones (Janakdev, Lbr 40 and PRP 266264.1). The results showed that the main effects of planting dates and potato clones significantly $(\mathrm{P}<0.05)$ affected most growth, yield and yield attributing parameters of the crop. Interaction effect of planting dates and potato clones also significantly influenced the number of above-ground stems per plant, ground cover percentage, number of tubers per plant, number and weight of small size tuber $(<25 \mathrm{~g})$, weight of medium or seed size $(25-50 \mathrm{~g})$ tuber and large size $(>50 \mathrm{~g})$ tuber, number and yield of tubers per plot, and yield t/ha. The highest yield (37.05 t/ha) was obtained from $14^{\text {th }}$ November planting. The clone Lbr 40 produced a higher yield (36.05t/ha). The clone PRP 266264.1 planting on $30^{\text {th }}$ October planting produced significantly a higher yield $(41.34 \mathrm{t} / \mathrm{ha})$. The clone Lbr 40 produced significantly highest number and weight of large size $(>50 \mathrm{~g})$ tuber. Number of small size $(<25 \mathrm{~g})$ tuber per plot or unmarketable tuber significantly increased on delayed planting.
\end{abstract}

Keywords: Clones, Potato, Planting dates, Tuber, Yield

Correct citation: Adhikari, S., Srivastava, A. K., Sharma, M., \& Shrestha, A.K. (2020). Response of potato clones to planting dates in Pokhara, Kaski, Nepal. Journal of Agriculture and Natural Resources, 3(2), 175-183. DOI: https://doi.org/10.3126/janr.v3i2.32503

\section{INTRODUCTION}

Potato (Solanum tuberosum L.) is the most important tuber crop in Nepal. It is an important food and vegetable crop which produces more food per unit area and time as compared to cereals. Globally, it is grown in more than 150 countries in a wide variety of soils and climates (FAO, 2014). In Nepal, the area under potato was 193,997 hectares and the total production was 3,112,947 tons with productivity of 16.04 ton/ha (ABPSD, 2019). It is commercial non-cereal produce of Nepal and an important source of income for the farmers (Upadhyay et al., 2020). It is mainly grown and utilized as vegetables in plains and mid-hills (Kafle \& Shah, 2012), but one of the major staple food crops in the high-hills (Kafle \& Shah, 2012; Timsina et al., 2011; Subedi et al., 2019). Planting time is an important factor, which affects crop emergence, crop growth, crop duration, and tuber yield. The differences in crop 
growth and yield due to planting dates can be attributed largely to the differences in environmental parameters such as day and night temperature, photoperiod, and photosynthetically active radiations (Jones \&Allen, 1983). For each type of crop, appropriate and proper time of planting is one of the basic requirements for maximum yield and high-profit returns. Nepal is a small country with large environmental variation. Either early planting or late planting can result in lower yield because the probability exists that unfavorable climatic conditions can occur after planting or during the growing season (Sandhu et al., 2013). It is necessary to find out proper planting time for out yielded variety as the farmers obtain good earning by producing valuable crops. In order for crop to best utilize moisture, nutrient and solar radiation, they must be grown from optimum sowing dates.

Since limited work has been done on these aspects under the Pokhara valley condition, the present investigation was conducted to find out the optimum planting time with specific variety for getting better yield and quality of potato sustainably.

\section{MATERIALS AND METHODS}

\section{Description of Experimental Site}

The experiment was conducted in vegetable research unit of Horticulture Reasearch Station, Malepatan, Pokhara, Kaski district in western Nepal during 2015/2016 cropping season under irrigated condition. The area is $203 \mathrm{~km}$ away from southwest of Kathmandu, located at about $28^{\circ} 13^{\prime} 6.8^{\prime \prime} \mathrm{N}$ latitude and $83^{\circ} 58^{\prime} 27.72^{\prime \prime} \mathrm{E}$ longitude and at elevation of $848 \mathrm{~m}$. a. s. 1 . The station has sub-tropical humid type of climate. The soils are deep, well-drained and sandy loam in texture. The area receiving an average annual rain fall of 3800-4200 $\mathrm{mm}$ and annual mean temperature ranges between $16.3^{\circ} \mathrm{c}-27.7^{\circ} \mathrm{c}$. During the experimental period, the lowest amount of precipitation (nil) was in months of December, while the highest $(99.5 \mathrm{~mm}$ ) was in months of March (HRS, 2016).

\section{Experimental Treatments, Design and Procedures}

Potato clones namely Janakdev, Lbr 40, and PRP 266264.1 obtained from Horticulture Research Station, Malepatan, Pokhara were used for the experiment. All the potato clones are relatively resistant to late blight disease. (HRS, 2013). Three planting times (October 30, November 14, and November 29) in factorial combination with three clones (Janakdev, Lbr 40 and PRP 266264.1) arranged in randomized complete block design with three replicates. The whole field was divided into three blocks each containing 9 plots. The size of each unit plot was $7.2 \mathrm{~m}^{2}(3 \mathrm{mX} 2.4 \mathrm{~m})$, having intra and inter row spacing of $0.25 \mathrm{~m}$ and $0.6 \mathrm{~m}$ respectively. A distance of $0.5 \mathrm{~m}$ and $1 \mathrm{~m}$ was maintained between unit plot and blocks, respectively. Each plot had four rows which consisted of twelve hills. Seed tubers of each variety were planted by hand three times at fifteen days interval starting from October 30 to November 29 in furrows. Management practices such as weeding; cultivation and ridging were practiced as per the general recommendation for potato given by National Potato Research Program, Khumaltar, Nepal. Fertilizers were applied as per the general recommendation of (NPRP, 2015), accordingly, 20 ton Farm Yard Manure, $100 \mathrm{~kg}$ N, $100 \mathrm{~kg}$ of $\mathrm{P}_{2} \mathrm{O}_{5}$ and $60 \mathrm{~kg} \mathrm{~K} \mathrm{~K}_{2} \mathrm{O} / \mathrm{ha}$.

\section{Data Collected and Analysis}

To evaluate the effect of planting date and clones on tuber yield of potato; data were collected for growth parameters such as emergence percentage at $15^{\text {th }}$ and $30^{\text {th }}$ days after planting, number of main stems per plant, ground cover percentage, plant height, number and weight 
of different sizes of tuber per plot, and total yield t/ha. Number of main stems per plant, ground cover and plant height recorded at 60 days after planting. The data were checked for meeting all ANOVA assumptions and subjected to Analysis of variance (ANOVA) using GENSTAT $15^{\text {th }}$ Edition. For segregation of means, Duncan's Multiple Range Test (DMRT) was used. The significant differences between varieties were determined using the least significant difference (LSD) test at $1 \%$ or $5 \%$ level of significance (Gomez and Gomez 1984; Shrestha, 2019).

\section{RESULTS AND DISCUSSION}

\section{Percentage of Emergence}

There was significant variation observed on the effect of date of planting on emergence $\%$ at 30 DAP but not found at 15 DAP (Table 1). At 30 DAP, the highest emergence percentage was observed in $14^{\text {th }}$ November (93.98) planting which was statistically similar to $30^{\text {th }}$ October (93.29) planting, and the significantly lowest emergence percentage was found in $29^{\text {th }}$ November planting.

The lesser emergence percentage at 15 DAP might be due to the presence of some growth inhibitors in seed tuber. Burton and Meigh (1971) also reported that benzothiazole, 1, 4dimethyl naphthalene, and 1, 6 dimethyl naphthalene are comparatively potent inhibitors of sprout growth in the tuber. In the $29^{\text {th }}$ November planting, the seed tuber became physiologically aged which have multiple and thinner sprouts that might be injured while covering by soil during planting. Vander Zaag (1992) reported that if the sprout breaks off, its base remains there is a fair chance that the bottom lateral buds, which normally form stolons, will grow into one or more stems, all of which arise from the same eye and it took the time to emerge from the soil surface.

\section{Number of stems}

There was significant variation observed in the number stems per plant by the effect of date of planting (Table 1). Planting on $29^{\text {th }}$ November produced a significantly higher number of stems (5.36) while the minimum (4.44) stems per plant were in $30^{\text {th }}$ October planting. The number of stems per plant was highly significant due to clones at 60 days after planting (Table 1). Variety Janakdev produced a significantly higher number of above-ground stems per plant (6.49) while the minimum number of stems produced by Lbr 40 (3.76).

It was observed that delay in planting resulted in an increased number of above-ground stems per plant. Tubers used for planting in the trial were stored in cold storage from $15^{\text {th }}$ March 2014 to $20^{\text {th }}$ October 2015. The tubers were taken out of storage and kept at room temperature for six weeks where they take time and sprouts before they get planted. Seed tubers used for the present study were taken out of the cold store in October just ten days before the first sowing. The rest of the seed was kept at room temperature and was planted every fortnight for successive dates of planting. The seed tubers planted at the earliest dates received shorter time at room temperature as compared to tubers used for later plantings. Earlier planted tubers produced lesser sprouts before sowing while tubers planted later had already sprouted and produced the maximum number of sprouts before sowing, which finally resulted in a higher number of stems per plant at late planting. Bohl (1995) compared the seed tubers of two ages; old vs. young and reported that young seed grew slower and produced fewer stems per plant while older seed had rapid growth and produced more stems per hill. Similar findings were reported by Khan et al. (2011). The ability of potato plants to 
produce many shoots per hill depends on their genotypic character. Jalil et al. (2004) reported that the Cardinal variety produced more number of shoots per plant than Lal-Pakhri. Dhakal (2011) found a highly significant effect of varieties on the number of shoots per plant. Kufri Chipsona-2 produced a significantly higher number of stems per plant at all stages of plant growth. The maximum number of stems per plant (4.36) was obtained in Kufri Chipsona-2 at 75 DAP. The highest number of main stems per plant in the Janakdev variety might be due to varietal characters.

\section{Ground coverage}

There was a highly significant difference in ground cover percentage among the different dates of planting (Table 1). The highest percentage of the ground cover was observed in $14^{\text {th }}$ November planting $(90.11 \%)$ which was statistically similar to $30^{\text {th }}$ October $(89.11 \%)$ planting. The lowest ground cover percentage was found on $29^{\text {th }}$ November planting. The effect of variety on ground cover percentage was highly significant (Table 1). The highest ground cover percentage (87.56\%) was recorded from PRP 266264.1 while the lowest was from Janakdev which was at par with Lbr 40. Well-developed foliage with a maximum ground cover of a plant indicates its good growth and development (Mahmud, 2012). The ability of plants to produce leaves and stems per plant depends upon the genetic makeup of the crop which consequently affects ground cover. The highest ground cover percentage in PRP 266264.1 might be due to varietal characters. Planting on $14^{\text {th }}$ November and $30^{\text {th }}$ October occurred in a congenial environment in terms of temperature and sunny days which might have influenced the vegetative growth as well as a ground cover percentage.

\section{Plant height}

The effect of date of planting on plant height in $\mathrm{cm}$ is presented in Table 1 . The plant height was significantly influenced by planting dates. Planting on $14^{\text {th }}$ November attained the maximum height $(73.02 \mathrm{~cm})$ which was statistically similar to the $30^{\text {th }}$ October $(69.76 \mathrm{~cm})$. The shortest plant height was found in $29^{\text {th }}$ November planting $(60.64 \mathrm{~cm})$. The result revealed that there was a significant difference in plant height among the tested clones. The tallest clone was Lbr $40(71.67 \mathrm{~cm})$ followed by PRP $266264.1(69.67 \mathrm{~cm})$ while the shortest clone was Janakdev $(62.09 \mathrm{~cm})$.

Table 1.Effect of date of planting and clones on vegetative parameters for ware potato production at Horticulture Research Station, Malepatan, Pokhara, Nepal during 2015/016

\begin{tabular}{lccccc}
\hline Treatment & $\begin{array}{c}\text { Emergence } \% \\
(15 \text { DAP) }\end{array}$ & $\begin{array}{c}\text { Emergence } \% \\
(30 \text { DAP) }\end{array}$ & $\begin{array}{c}\text { Number of above- } \\
\text { ground stems/ plant }\end{array}$ & $\begin{array}{c}\text { Ground cover } \\
\%\end{array}$ & $\begin{array}{c}\text { Plant height } \\
(\mathrm{cm})\end{array}$ \\
\hline Date of planting (Fa) & & & & & \\
$\mathrm{D}_{1}\left(30^{\text {th }}\right.$ October) & 35.2 & $93.29^{\mathrm{a}}$ & $4.44^{\mathrm{b}}$ & $89.11^{\mathrm{a}}$ & $69.76^{\mathrm{a}}$ \\
$\mathrm{D}_{2}\left(14^{\mathrm{th}}\right.$ November) & 38.4 & $93.98^{\mathrm{a}}$ & $4.82^{\mathrm{ab}}$ & $90.11^{\mathrm{a}}$ & $73.02^{\mathrm{a}}$ \\
$\mathrm{D}_{3}\left(29^{\text {th }}\right.$ November) & 27.1 & $86.11^{\mathrm{b}}$ & $5.36^{\mathrm{a}}$ & $72.22^{\mathrm{b}}$ & $60.64^{\mathrm{b}}$ \\
\hline F Test & $\mathrm{NS}$ & $*$ & $*$ & $* *$ & $* *$ \\
\hline Clones (Fb) & & & & & \\
$\mathrm{V}_{1}($ Janakdev $)$ & 38.9 & 90.45 & $6.49^{\mathrm{a}}$ & $80.56^{\mathrm{b}}$ & $62.09^{\mathrm{b}}$ \\
$\mathrm{V}_{2}($ Lbr 40) & 43.5 & 91.65 & $3.76^{\mathrm{c}}$ & $83.33^{\mathrm{b}}$ & $71.67^{\mathrm{a}}$ \\
$\mathrm{V}_{3}$ (PRP 266264.1) & 18.3 & 91.28 & $4.38^{\mathrm{b}}$ & $87.56^{\mathrm{a}}$ & $69.67^{\mathrm{a}}$ \\
\hline F Test & $\mathrm{NS}$ & $\mathrm{NS}$ & $* *$ & $* *$ & $* *$ \\
CV $(\%)$ & 66.3 & 5.3 & 12.5 & 3.5 & 5.41 \\
\hline
\end{tabular}

Means in the column followed by same letter in each treatments do not differ significantly at $(\mathrm{p}=0.05)$ by DMRT. DAP $=$ Days after planting, and $C V=$ Coefficient of variation, DAP=Days after planting 
Plant height is a desirable character that contributes to the increment of plant canopy and biomass. The higher biomass has the capacity for higher photosynthetic rates and translocation to sink (tuber) resulting in higher yield. The variation in plant height may be due to food reserve for the early growth of seed tubers and varietal characters and interactions of planting materials and the environment. Wiersema (1986) and Batra et al. (1992) reported similar findings. The difference in plant height for different planting dates indicated that low temperature and soil moisture might be the reasons for the poor growth vigor of potato planted on $29^{\text {th }}$ November during its early stage. Plant height can steadily increase until the middle and later periods of tuber formation stage if there was sufficient moisture.

\section{Number and weight of tubers}

The effect of planting dates on the number of small sizes $(<25 \mathrm{~g})$ tubers per plot was found significant (Table 2). The significantly higher number of small tubers found in $29^{\text {th }}$ November planting (168.80). In the case of the weight of small tuber $(<25 \mathrm{~g})$, there was no significant difference observed by the effect of the date of planting. The influence of clones on the number and weight of small size $(<25 \mathrm{~g})$ tubers per plot were highly significant (Table 2). The clone PRP 266264.1 produced a significantly higher number of small size tubers (208.7). The clone PRP 266264.1 produced the highest weight of small size tubers $(2.48 \mathrm{~kg})$. The clone PRP 266264.1 produced the highest number $(225)$ and weight $(8.32 \mathrm{~kg})$ of medium size tuber. Janakdev and Lbr 40 were at par on the number and weight of medium size tuber production. There were significant variations observed in the number and weight of large tubers per plot by the effect of date of planting (Table 2). Tuber planted at $14^{\text {th }}$ November produced the higher number of large tubers $(231.60)$ and weight $(19.07 \mathrm{~kg})$ per plot. The lower number of large tubers (158.3) was produced in $30^{\text {th }}$ October planting and lower weight $(13.8 \mathrm{~kg})$ in $29^{\text {th }}$ November planting. The effect of clones on the number and weight of large size tuber was highly significant (Table 2). The number and weight of large size tubers were highest in LBR 40 and significantly superior over the rest of the treatments. The number and weight of large size tuber production of Janakdev and PRP266264.1 were at par.

A reverse trend was observed for small tubers, delay in planting significantly increased the number of small-sized tubers $(<25 \mathrm{~g})$. Plant growth in delayed planting significantly reduced the vegetative growth of the potato plant because of lower temperatures in December and January. It was most likely that tuber initiated earlier could get larger but poor vegetative growth, at late planting with shortened growth period, was unable to transform sufficient energy to the stolons or tubers due to sub-optimal environmental conditions which favored the high number small size tuber. Delayed planting and earlier harvesting resulted in a higher number of the small sized tubers. The same trend, as observed in this work, has been reported by Torres (1979) and Khan et al. (2011) who observed that late planting and early harvesting always produced a higher percentage of small-sized tubers. Tubers planted in earlier dates received more time of optimum temperatures than the late planting, which resulted in a higher number of marketable tubers. On the other hand, delay in harvesting always produced maximum number and weight of marketable tubers, i.e. longer the period the better the tuber size. The data trend set in the interaction revealed that the weight of seed size and large size tuber is high in $14^{\text {th }}$ November planting however it might be affected by varietal characteristics. The Lbr 40 on $29^{\text {th }}$ November planting also gave large size tuber weight. The phenomenon is well supported by Ahmad and Rashid (1980) who recorded reduced tuber count with delay in planting. In the present study, planting on $30^{\text {th }}$ October and $14^{\text {th }}$ November provided a maximum period of optimal temperature and sunshine for crop development which resulted in excellent foliage growth with improved photosynthesis which 
ultimately helped to increase the size of tubers. Since earlier planting improved vegetative growth and provided a longer period of favorable conditions to the plants, therefore, the same planting resulted in a higher number of large-sized tubers. Similarly delayed planting provided a longer period to the tubers to grow larger. Ahmad and Rashid (1980) reported a similar trend of producing larger tubers at earlier plantings.

\section{Tuber yield}

The effect of date of planting on yield t/ha was highly significant (Table 2). The highest yield (37.05 t/ha) was obtained in $14^{\text {th }}$ November planting which was not significantly different from the $30^{\text {th }}$ October while the lowest yield $(27.38 \mathrm{t} / \mathrm{ha})$ was obtained in $29^{\text {th }}$ November planting. The effect of potato clones on yield was highly significant (Table 2). The highest yield (36.05 t/ha) were obtained from Lbr 40 which was not significantly different from the PRP 266264.1. The variety Janakdev produced the lowest yield (28.34 t/ha).

Table 2.Effect of date of planting and clones on tuber size per plot and yield $\mathrm{t} / \mathrm{ha}$ for ware potato production at Horticulture Research Station, Malepatan, Pokhara, Nepal during 2015/016

\begin{tabular}{|c|c|c|c|c|c|c|c|}
\hline \multirow{3}{*}{ Treatment } & \multicolumn{6}{|c|}{ Tuber size per plot } & \multirow{3}{*}{ Yield t/ha } \\
\hline & \multicolumn{2}{|c|}{$<25 \mathrm{~g}$} & \multicolumn{2}{|c|}{$25-50 \mathrm{~g}$} & \multicolumn{2}{|c|}{$>50 \mathrm{~g}$} & \\
\hline & No. & Wt. $(\mathrm{kg})$ & No. & Wt.(kg) & No. & Wt.(kg) & \\
\hline \multicolumn{8}{|l|}{ Date of planting $(\mathrm{Fa})$} \\
\hline $\mathrm{D}_{1}\left(30^{\text {th }}\right.$ October $)$ & $114.00^{\mathrm{b}}$ & 1.63 & 137.0 & 6.07 & $158.30^{\mathrm{b}}$ & $17.73^{\mathrm{a}}$ & $35.34^{\mathrm{a}}$ \\
\hline $\mathrm{D}_{2}\left(14^{\text {th }}\right.$ November $)$ & $133.20^{\mathrm{b}}$ & 1.41 & 158.0 & 6.20 & $231.60^{\mathrm{a}}$ & $19.07^{\mathrm{a}}$ & $37.05^{\mathrm{a}}$ \\
\hline $\mathrm{D}_{3}\left(29^{\text {th }}\right.$ November $)$ & $168.80^{\mathrm{a}}$ & 1.22 & 146.0 & 4.69 & $198.00^{\mathrm{ab}}$ & $13.80^{\mathrm{b}}$ & $27.38^{\mathrm{b}}$ \\
\hline F Test & $*$ & NS & NS & NS & $*$ & $*$ & $* *$ \\
\hline \multicolumn{8}{|l|}{ Clones $(\mathrm{Fb})$} \\
\hline $\mathrm{V}_{1}($ Janakdev $)$ & $93.90^{\mathrm{b}}$ & $0.99^{\mathrm{b}}$ & $124.0^{\mathrm{b}}$ & $4.37^{\mathrm{b}}$ & $179.00^{\mathrm{b}}$ & $15.04^{\mathrm{b}}$ & $28.34^{\mathrm{b}}$ \\
\hline $\mathrm{V}_{2}(\operatorname{Lbr} 40)$ & $91.70^{\mathrm{b}}$ & $0.79^{\mathrm{b}}$ & $91.0^{\mathrm{b}}$ & $4.27^{\mathrm{b}}$ & $215.80^{\mathrm{a}}$ & $20.89^{\mathrm{a}}$ & $36.05^{\mathrm{a}}$ \\
\hline $\mathrm{V}_{3}(\mathrm{PRP} 266264.1)$ & $230.40^{\mathrm{a}}$ & $2.48^{\mathrm{a}}$ & $225.0^{\mathrm{a}}$ & $8.32^{\mathrm{a}}$ & $193.10^{\mathrm{b}}$ & $14.67^{\mathrm{b}}$ & $35.38^{\mathrm{a}}$ \\
\hline F Test & $* *$ & $* *$ & $* *$ & $* *$ & $* *$ & $* *$ & $* *$ \\
\hline $\mathrm{CV}(\%)$ & 22.6 & 20.2 & 23.8 & 18.6 & 22.6 & 18.2 & 9.9 \\
\hline
\end{tabular}

Means in the column followed by the same letter in each treatment do not differ significantly at $(\mathrm{p}=0.05)$ by DMRT. DAP= Days after planting, and $\mathrm{CV}=$ Coefficient of variation

Since earlier planting and late harvesting produced a higher number of larger and mediumsized tubers, this also contributed to the total yield. As the planting delayed the yield was reduced. On the other hand, delaying the harvesting improved the yield. Similar results were reported by Khan et al. (2011). Other studies also confirm that potato tuber yield increased with late harvesting (Workman \& Harrison, 1980). Data collected also support the results regarding tuber yield as the vegetative growth was significantly improved by planting the crop earlier and harvesting later, which increased the number of large and medium-sized tubers and decreased the small-sized tubers. Light interception is directly correlated with ground cover and it was highest in $14^{\text {th }}$ November and $30^{\text {th }}$ October planting which might be the cause of higher yield. The total interception of light over the season is related to total tuber yield (Ezekiel \& Bhargava, 1992; Roy \& Jaiswal 1998). The ground cover percentage was lowest in the $29^{\text {th }}$ November planted crop; therefore, it resulted in the lowest tuber yield in the investigation. These results were in close agreement with those of Pandey \& Ghai (1975), Sharma \&Verma (1987); Ezekiel \& Bhargava (1992); Khan et al. (2011); Sandhu et al. (2013). The frost occurred in mid-January which affected the tender plants of $29^{\text {th }}$ November planting compare to $14^{\text {th }}$ November and $30^{\text {th }}$ October planting might be the cause of low yield in delayed planting. 


\section{CONCLUSION}

Potato is one of the important vegetable and food crops grown in Nepal. Unavailability of quality planting materials, lack of suitable high yielding varieties, lack of knowledge of appropriate date of planting in each agro-ecological domain are some of the problems faced by potato growers of Nepal. From this research, in the context of Pokhara valley, Potato planting at $14^{\text {th }}$ November produced a significantly higher yield. Potato clone Lbr 40 produced a significantly higher total yield. Delayed planting from $14^{\text {th }}$ November onwards significantly reduced the marketable and total tuber yield.

\section{ACKNOWLEDGEMENT}

The kind-hearted treatment and warm welcome offered to authors by the staff of the Horticulture Research Station, Malepatan, Pokhara was sincerely appreciated. The authors would like to thank for Nepal Agricultural Research Council for nomination for postgraduate study and provide financial assistance throughout the study.

\section{Authors' Contributions}

S.A. designed, performed and analyzed the experiment. A.K. Srivastava supervised the experiment and M.D.S. and A.K.S. contributed to interpret the result.

\section{Conflict of Interest}

The authors declare no conflicts of interest regarding publication of this manuscript.

\section{REFERENCES}

ABPSD. (2019). Statistical Information on Nepalese Agriculture. Agri-Business Promotion and Statistical Division, Singhdurbar, Kathmandu.

Ahmad, U. K., \& Rashid A. (1980). Effect of date of planting on the production of potatoes. Bangladesh J. Agric. Res., 5(2), 21-26.

Batra, V. K., Malik, Y. S., Pandita, M. L., \& Khurana, S. C. (1992). Effect of seedling tuber size, spacing and method of planting on potato production. J Indian Pot Assoc, 19, 166-170.

Bohl, W. H. (1995). Potato seed management: seed size and age. University of Idaho, College of Agriculture, Cooperative Extension System, Agricultural Experiment Station.

Burton, W. G., \& Meigh, D. F. (1971). The production of growth-suppressing volatile substances by stored potato tubers. Potato Research, 14(2), 96-101.

Cho, J. L., \& Iritani, W. M. (1983). Comparison of growth and yield parameters of Russet Burbank for a two-year period. American potato journal, 60(8), 569-576.

Dhakal, R. (2011). Response of Chips Potato Varieties to Potash and Mulching Levels on Tuber Yield and Quality Chips at Divyapuri, Nawalparasi, Nepal (M.sc.Ag. Thesis, Tribhuwan University)

DOI: https://dx.doi.org/10.26832/24566632.2019.040109

Ezekiel, R., \& Bhargava, S. C. (1992). Physiological analysis of growth of potato in relation to planting date. Indian Journal of Plant Physiology, 35, 56-56.

FAO. (2014). FAO Statistical Year Book. Asia and the Pacific Food and Agriculture.

Gomez, K.A., \& Gomez, A.A. (1984). Statistical procedures for agricultural research. $2^{\text {nd }}$ edn.International Rice Research Institute, College, Laguna, pp. 680.

HRS (2013). Annual Report 2069/70 (2012/13). Horticulture Research Station, NARC, Malepatan, Pokhara 
HRS (2016). Annual Report 2072/73 (2015/16) (Adhikari S, TR Pokhrel and LN Aryal, eds). Horticulture Research Station, NARC, Malepatan, Pokhara

Jalil, M. A., Azad, M. A. K., \& Farooque, A. M. (2004). Effect of different mulches on the growth and yield of two potato varieties. J. Biol. Sci, 4, 331-333.

Jones, J. L., \& Allen, E. J. (1983). Effects of date of planting on plant emergence, leaf growth, and yield in contrasting potato varieties. The Journal of Agricultural Sciences, 101, 81-95

Kafle, B.,\& Shah, P. (2012). Adoption of improved potato varieties In Nepal: A case of Bara district. Journal of Agricultural Sciences, 7(1). DOI: 10.4038/jas.v7i1.4063

Khan, A. A., Jilani, M. S., Khan, M. Q., \& Zubair, M. (2011). Effect of seasonal variation on tuber bulking rate of potato. The Journal of Animal \& Plant Science, 21(1), 31-37.

Mahmud, A. A. (2012). Improvement of drought tolerant potato variety. A Ph. D Dissertation. Dept of Horticulture, Banngabandhu Sheikh Mujibur Rahman Agricultural University, Gazipur, Bangladesh.

NPRP (2015). Annual Report 2071/72 (2014/15). National Potato Research Program, NARC, Khumaltar, Lalitpur

Panday, J., \&Ghai, V. P. (1975). Effect of date of planting, spacing, levels of nitrogen and size of tuber on the yield of seed potato. Indian journal of agronomy.

Rashid, M.M. (1987). Problem of production of true potato seeds in Bangladesh. In Proceeding of Workshop on True Potato Seed (TPS) in Bangladesh. Potato Research Center. BARI. Gazipur, Bangldesh (pp.5-7).

Roy, S. K., \& Jaiswal, V. P. (1998). Response of potato (Solanum tuberosum) to planting dates and nitrogen. Indian Journal of Agronomy, 43(3), 484-488.

Sandhu, A.S., Sharma, S.P., Bhutani, R.D., \& Khurana, S.C. (2013). Potato (Solanum tuberosum L.) tuber yield as affected by planting times and fertilizer doses under sandy loams soils. Indian Journal of Agriculture Research, 47(6): 496-502

Sharma, I. P., \&Verma, U. K. (1987). Effect of planting and harvesting dates on yield and yield attributes of potatoes. Journal of Potato Association, 14(1), 48-51.

Shrestha, J. (2019). P-Value: A True Test of Significance in Agricultural Research, https://www.linkedin.com/pulse/p-value-test-significance-agricultural-research-jibanshrestha/. DOI: http://doi.org/10.5281/zenodo.4030711

Subedi, S., Ghimire, Y.N., Gautam, S., Poudel, H.K., \& Shrestha, J. (2019). Economics of potato (Solanum tuberosum L.) production in terai region of Nepal. Archives of Agriculture and Environmental Science, 4(1), 57-62.

Timsina, K. P., Kafle, K., \& Sapkota, S. (2011). Economics of potato (Solanum tuberosum L.) production in Taplejung district of Nepal. Agronomy Journal of Nepal, 2, 173181.

Torres, W. (1979). Influence of different planting dates on the growth of potato (Solanum Tuberosum L.) Tubers Cv. Desiree. Field Crop Abstract, 35, 5392.

Upadhyay, K.P., Dhami, N.B., Sharma, P.N., Neupane, J.D., \& Shrestha, J. (2020). Growth and yield responses of potato (Solanum tuberosum L.) to biochar. Agrarian Science, 31 (2): In Press. doi: 10.15159/jas.20.18.

Van der Zaag, D. E. (1992). Potatoes and their cultivation in the Netherlands. The Hague, Netherlands: Dutch Information Center for Potatoes.

Wiersema, S. G. (1986). The effect of density on tuber yield in plants grown from true potato seed in seed beds during two contrasting seasons. American potato journal, 63(9), $465-472$ 
Journal of Agriculture and Natural Resources (2020) 3(2): 175-183

ISSN: 2661-6270 (Print), ISSN: 2661-6289 (Online)

DOI: https://doi.org/10.3126/janr.v3i2.32503

Workman, M., \& Harrison, M. D. (1980). The influence of harvest date on yield, early-blight tuber infection and chipping characteristics of potatoes grown with sprinkler irrigation [Colorado]. General Series-Colorado State University Experiment Station (USA). 